\title{
Polyurethanes Based on Atactic Poly[(R,S)-3-hydroxybutyrate]: Preliminary Degradation Studies in Simulated Body Fluids
}

\author{
Joanna Brzeska $\cdot$ Aleksandra Heimowska • \\ Henryk Janeczek • Marek Kowalczuk • \\ Maria Rutkowska
}

Published online: 7 March 2014

(C) The Author(s) 2014. This article is published with open access at Springerlink.com

\begin{abstract}
The aliphatic polyurethanes based on atactic poly $[(R, S)$-3-hydroxybutyrate] (a-PHB) and commercial oligomerols: poly( $\varepsilon$-caprolactone)diol and polyoxytetramethylenediol were investigated. a-PHB was obtained by anionic ring-opening polymerization of $(R, S)$ - $\beta$-butyrolactone. The $4,4^{\prime}$-methylenedicyclohexyl diisocyanate and 1,4-butanediol were used as contributors of hard segments. The aim of the study was to determine the influence of synthetic, atactic a-PHB in soft segments of polyurethanes on their degradability in simulated body fluids (SBF) and Ringer solution. The incubation of polymer samples in both degradative solutions was carried out for 36 weeks. It was concluded that the presence of a-PHB in polyurethane structure accelerated their degradation in SBF and in Ringer solution and, protected the calcification process.
\end{abstract}

Keywords Polyurethanes - Atactic poly $[(R, S)-3-$ hydroxybutyrate] · Body fluids · Degradability

J. Brzeska $(\bowtie) \cdot$ A. Heimowska · M. Rutkowska

Department of Chemistry and Commodity Industrial Science, Gdynia Maritime University, 83 Morska Street, 81-225 Gdynia, Poland

e-mail: j.brzeska@wpit.am.gdynia.pl

H. Janeczek · M. Kowalczuk

Centre of Polymer and Carbon Materials, Polish Academy of

Sciences, 34 Sklodowska-Curie Street, 41-819 Zabrze, Poland

M. Kowalczuk

School of Biology, Chemistry and Forensic Science, Faculty of

Science and Engineering, University of Wolverhampton,

Wolverhampton WV1 1SB, UK

\section{Introduction}

Polyurethanes are commonly used in medicine as degradable and non-degradable implants [1, 2]. The unique combination of their properties as flexibility, toughness and biocompatibility makes them a proper material for medical engineering. For the tissue regeneration process the physico-mechanical properties of the implanted material must be similar to the surrounding natural tissue. If required, the implant should also degrade at a rate similar to the native tissue regeneration process. The biodegradability of polyurethanes can be accelerated by using appropriate substrates for their creation.

Polyesterols such as poly( $\varepsilon$-caprolactone)diol (PCL) and polyetheroles such as polyoxytetramethylenediol (PTMG) can be incorporated into soft segments (SSs) of polyurethanes. PCL is a biocompatible, biodegradable and semicrystalline aliphatic polyester, well known for possessing a valuable set of properties, such as nontoxicity for living organisms and resorption after an appropriate period of implantation time. It undergoes the enzymatic degradation and slow hydrolytical processes. The hydrolysis of the ester linkage is the main mechanism of PCL biodegradation [3]. Whereas PTMG oligoetherol, used as SSs of polyurethanes, degrades mainly by oxidizing mechanisms [4].

Atactic poly[(R,S)-3-hydroxybutyrate] (a-PHB), the synthetic amorphous analog of natural polyhydroxybutyrate, is known as a biodegradable and biocompatible polymer [5, 6] and as a $\mathrm{OH}$-terminated polyol can also be incorporated into polyurethane structure. Previous work showed that the presence of a-PHB in polyurethane network influences their structural, thermal, mechanical and degradation properties [7-10]. Polyurethanes based on a-PHB do not affect the blood parameters in direct contact and seem to be biostatic against pathogenic microorganisms [10-12]. 
Furthermore, application of aliphatic diisocyanate for hard segment creation (instead of aromatic one) prevents the risk of aromatic diamine formation as a by-product of the polyurethane degradation.

We report in this current study on the influence of synthetic, atactic a-PHB used as a part of a SS of aliphatic polyurethanes on their degradability in simulated body fluid (SBF) and in Ringer solution. The rate of degradation was monitored by the weight loss of samples during incubation in solutions by the microscopic observations of sample surfaces and by evaluating its thermal properties using differential scanning calorimetry (DSC).

\section{Experimental}

Materials

The samples studied were obtained at our laboratories as described previously [7, 13]. Synthesis of polyurethanes was carried out in a two-step reaction, with molar ratio of $\mathrm{NCO}: \mathrm{OH}=3.7: 1$ or $2: 1$, respectively, at prepolymerization stage.

Hard segments of all polyurethanes were made from 4,4'-methylenedicyclohexyl diisocyanate ( $\mathrm{H}_{12} \mathrm{MDI}$ ) (Alfa Aesar) and 1,4-butanediol (1,4-BD) (Aldrich). SSs were formed from the mixture of synthetic a-PHB (Mn 2000) and PTMG (Mn 2000, Aldrich) or from a-PHB and PCL (Mn 1920, Aldrich). a-PHB was obtained by anionic ringopening polymerization of $(R, S)$ - $\beta$-butyrolactone initiated by 3 -hydroxybutyric acid sodium salt/18-crown-6 complex at room temperature and terminated with 2-bromoethanol [14].

Eight kinds of polyurethanes were studied. Two of them contained synthetic a-PHB and PTMG in SSs, with 14 and $17.5 \%$ of a-PHB in polymer bulk for PUR $_{\text {PTMG }+a-P H B / 3.7}$ and PUR $\mathrm{PTMG}_{\mathrm{P}+\mathrm{a}-\mathrm{PHB} / 2}$ respectively. SSs of the next two polyurethanes were built from a-PHB and PCL, also with 14 and $17.5 \%$ of a-PHB in polyurethane bulk for

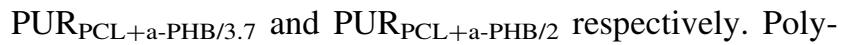
urethanes without a-PHB in SSs were investigated for comparison.

Investigated polyurethanes showed low-molecular masses $\left(M_{n}\right.$ ranging from 7,900 to 18,400$)$ and dispersity $\left(M_{w} /\right.$ $\mathrm{M}_{\mathrm{n}}$ ranging from 2.6 to 3.95) [9]. As it was described before, polyurethanes were hydrogen-bonded, and for samples that contained PTMG in SSs the creation of a small amount of allophanate structures was observed [9]. The wetting angle of polyurethanes based on a-PHB was ranged from $57.5^{\circ}$ to $64.6^{\circ}$, which has indicated on their hydrophility. It may therefore be expected that their hydrophility can facilitate their degradation [15].
Degradation in Simulated Body Fluid

Simulated body fluid was prepared as follows: firstly $8.035 \mathrm{~g} \mathrm{NaCl}, 0.355 \mathrm{~g} \mathrm{NaHCO}_{3}, 0.225 \mathrm{~g} \mathrm{KCl}, 0.231 \mathrm{~g}$ $\mathrm{K}_{2} \mathrm{HPO}_{4} \cdot 3 \mathrm{H}_{2} \mathrm{O}, 0.311 \mathrm{~g} \mathrm{MgCl} 2 \cdot 6 \mathrm{H}_{2} \mathrm{O}$ and $39 \mathrm{~mL}$ of $1 \mathrm{M}$ hydrochloric acid were dissolved into $750 \mathrm{~mL}$ of deionized water (UV sterilized), then $0.292 \mathrm{~g} \mathrm{CaCl}_{2}, 0.072 \mathrm{~g} \mathrm{Na}_{2} \mathrm{SO}_{4}$ and $6.118 \mathrm{~g}$ tris(hydroxymethyl) aminomethane were slowly added in turn. Finally the fluid was buffered to $1 \mathrm{~L}$ at physiological $\mathrm{pH} 7.4$ at $37{ }^{\circ} \mathrm{C}$ with dilute hydrochloric acid solution [16].

In vitro degradation in SBF was carried out for 4, 12, 24 and 36 weeks by immersing weighted polyurethanes samples in freshly prepared SBF. The medium was refreshed every week.

Degradation in Ringer Balanced Salt Solution

Ringer solution was prepared by dissolving four tablets (Merck) in $500 \mathrm{~mL}$ of deionized and UV sterilized water with sodium azide $(0.02 \%)$. Composition of one tablet was: $0.00525 \mathrm{~g} \mathrm{NH}_{4} \mathrm{Cl}, 0.005 \mathrm{~g} \mathrm{NaHCO}_{3}, 0.04 \mathrm{~g} \mathrm{CaCl}_{2}$. $2 \mathrm{H}_{2} \mathrm{O}, 0.00525 \mathrm{~g} \mathrm{KCl}$ and $1.125 \mathrm{~g} \mathrm{NaCl}$. Incubation of polymer samples was carried out at $37{ }^{\circ} \mathrm{C}$ for $4,12,24$ and 36 weeks. The incubating solution was replaced every month [17].

\section{The Weight Changes}

The polyurethanes were cut before incubation into samples with an area about $1 \mathrm{~cm}^{2}$, dried to a constant weight at $50{ }^{\circ} \mathrm{C}$ in vacuum drier, and weighed using an analytical balance. Next, they were immersed in sterilized containers and covered with appropriate solution using $10 \mathrm{~mL}$ per square of polymer sample and incubated in heating chamber in $37 \pm 1{ }^{\circ} \mathrm{C}$.

The samples were removed from each degradative solution at the given time, rinsed three times with distilled water, dried to a constant weight at $50{ }^{\circ} \mathrm{C}$ in vacuum drier and weighed to determine the weight change. The presented values of experimental weight changes were the arithmetic mean of three measurements.

\section{Differential Scanning Calorimetry}

Changes in thermal properties of polyurethane samples after their incubation in SBF and Ringer solutions were determined using of TA-DSC 2010 apparatus (TA Instruments, Newcastle, DE, USA). The instrument was calibrated with high purity indium. The degraded polyurethane samples were dried to constant weight before DSC measurement. The specimens were heated in sealed aluminium pans and scanned from -80 to $200{ }^{\circ} \mathrm{C}$ (first run) at heating 
Table 1 Composition of the obtained polyurethanes

\begin{tabular}{llcc}
\hline PUR & $\begin{array}{l}\text { Substrates used for SS } \\
\text { obtaining }\end{array}$ & $\begin{array}{l}\text { The percentage } \\
\text { of a-PHB in PUR } \\
\text { structure }(\%)\end{array}$ & $\begin{array}{l}\text { Molar ratio of } \\
\text { NCO:OH groups } \\
\text { in prepolymer }\end{array}$ \\
\hline PUR $_{\text {PTMG }+ \text { a-PHB/3.7 }}$ & PTMG + a-PHB & 14 & $3.7: 1$ \\
PUR $_{\text {PTMG/3.7 }}$ & PTMG & 0 & \\
PUR $_{\text {PCL }+ \text { a-PHB/3.7 }}$ & PCL + a-PHB & 14 & \\
PUR $_{\text {PCL/3.7 }}$ & PCL & 0 & $2: 1$ \\
PUR $_{\text {PTMG }+\mathrm{a}-\mathrm{PHB} / 2}$ & PTMG + a-PHB & 17.5 & \\
PUR $_{\text {PTMG/2 }}$ & PTMG & 0 & \\
PUR $_{\text {PCL }+ \text { a-PHB/2 }}$ & PCL + a-PHB & 17.5 & \\
PUR $_{\text {PCL/2 }}$ & PCL & 0 & \\
\hline
\end{tabular}

rate of $10{ }^{\circ} \mathrm{C} / \mathrm{min}$, rapidly cooled to $-80{ }^{\circ} \mathrm{C}$ and heated again to $200{ }^{\circ} \mathrm{C}$ (second run). All experiments were carried out under nitrogen atmosphere (flow of $50 \mathrm{~mL} / \mathrm{min}$ ). The melting temperature $\left(\mathrm{T}_{\mathrm{m}}\right)$ of the specimen was taken as the peak temperature maximum of the melting endotherm from first run, and the glass transition temperature $\left(\mathrm{T}_{\mathrm{g}}\right)$ was taken as the midpoint of the increase of the specific heat associated with the transition (second run). In case of polyurethanes obtained with $\mathrm{NCO}: \mathrm{OH}=3.7: 1$ and degraded in both solutions, the heating run was performed only to $160{ }^{\circ} \mathrm{C}$ because of their thermal degradation above that temperature.

\section{Microscopic Observation}

Microscopic observation of polymer surface changes during degradation was performed in reflected light with an optical microscope Nicon Alphaphot-2YS2 connected with digital photo camera Casio QY2900UX, at magnification $1: 300$.

\section{Results and Discussion}

Polyurethanes with various SSs and length of hard segments were studied and their compositions are summarized in Table 1.

The weight changes of polyurethane samples after incubation in SBF and in Ringer solution are presented in Figs. 1 and 2 respectively.

The mass changes of polymer samples with a-PHB after incubation in SBF indicated that polyurethanes with high content of hard segments (obtained at $\mathrm{NCO}: \mathrm{OH}=3.7: 1$ ) were degraded faster than polyurethanes with lower molar ratio of $\mathrm{NCO}: \mathrm{OH}$ in prepolymer (Fig. 1). It was observed both for both: polyether-esterurethane (Fig. 1a) and polyesterurethane (Fig. 1b). It could be expected that the higher amount of ester groups in the structure of PURs (obtained at $\mathrm{NCO}: \mathrm{OH}=2: 1$ in prepolymer) may facilitate
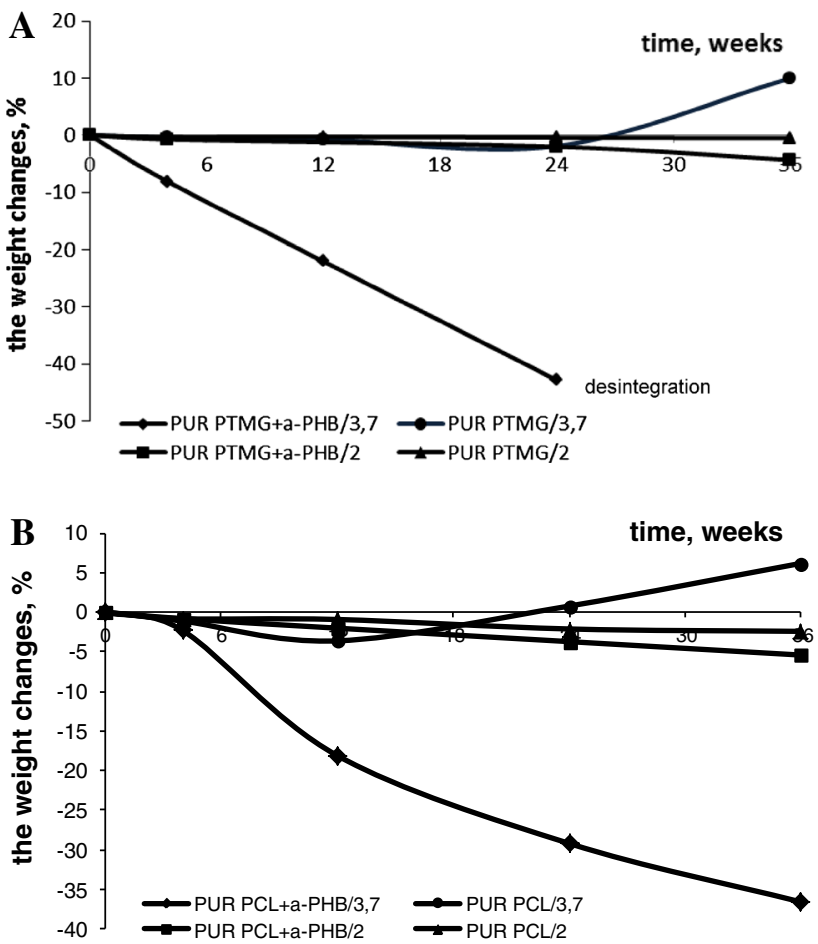

Fig. 1 The weight changes of polyether-esterurethane (a) and polyesterurethane (b) samples during incubation in SBF

the hydrolysis of PUR $\mathrm{PTMG}_{+\mathrm{a}-\mathrm{PHB} / 2}$ and $\mathrm{PUR} \mathrm{PCL}_{\mathrm{P}} \mathrm{a}-\mathrm{PHB} / 2$ as compared with PUR PTMG+a-PHB/3.7 and PUR $_{\text {PTMG+PCL/3.7 }}$ respectively. Moreover, the higher content of hard segments should cause the slower hydrolytic degradation of polyurethanes $[18,19]$. However, taking into consideration the generally lower density of our polyurethanes obtained at $\mathrm{NCO}: \mathrm{OH}=3.7: 1$ compared to $\mathrm{NCO}: \mathrm{OH}=2: 1$, in prepolymer step [15], the incubated medium with inorganic salts could easy diffuse into polymers network, which was observed. Only low decrease or even increase of samples mass after 36 weeks of incubation in SBF was indicated (Fig. 1).

In our previous study we demonstrated, that the decrease of molecular mass of all investigated polyurethanes after 
hydrolysis in phosphate buffer took place, which indicated on macrochains scission but only small weight loss of polymer samples was noticed [15].

Introducing of atactic a-PHB into the polymer structure accelerated the degradation of polyurethanes in SBF. It was
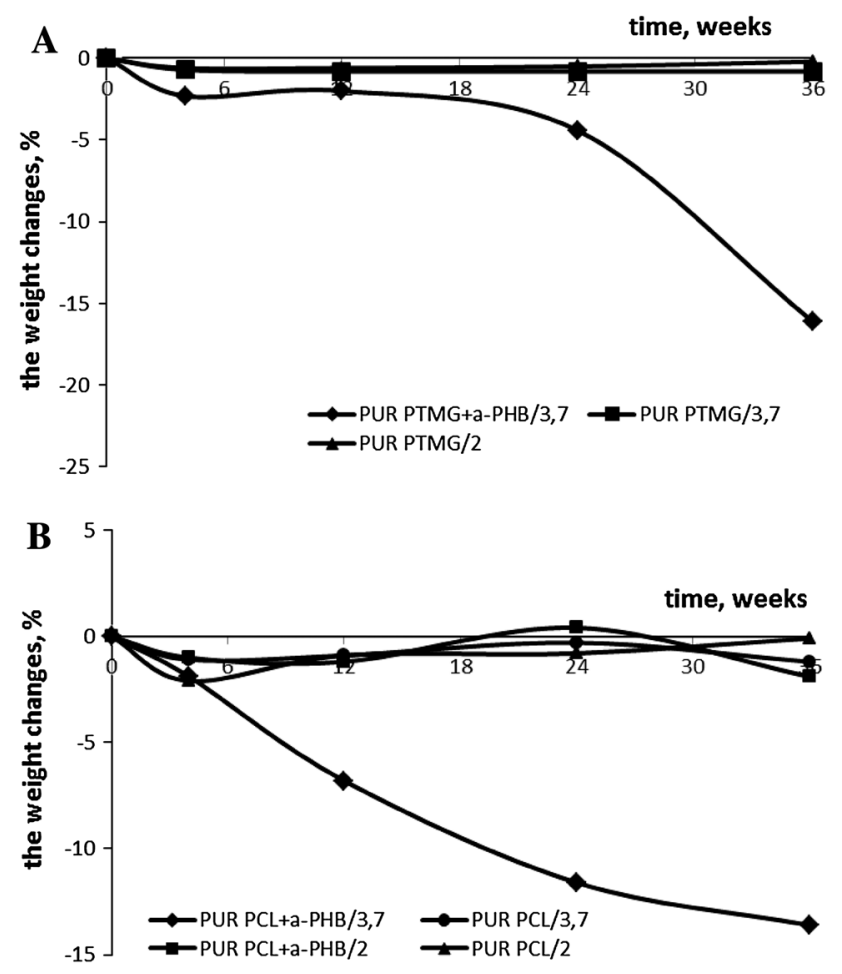

Fig. 2 The weight changes of polyether-ester-urethane (a) and polyesterurethane (b) samples during incubation in Ringer solution especially visible in case of polyurethanes with higher content of hard segments. Polyurethane with PTMG and

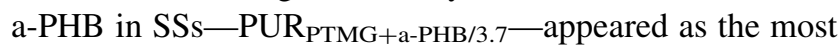
susceptible to SBF degradation from the all investigated polymers. It may be supposed that the water penetration into the polymer network followed by the hydrolysis of macrochains was facilitated due to more amorphous morphology of this polyurethane (Tables 3, 4, 5, 6). Because of the presence of ether groups in SSs (not susceptible to hydrolysis) this polyurethane degrades mostly via chemical breakage of the urethane bonds joining hard and SSs [20].

Previous hydrolytic degradation studies showed that PUR $_{\text {PTMG+a-PHB/3.7 underwent the hydrolysis after }}$ 36 weeks of incubation in phosphate buffer. The sample mass was reduced by about $61 \%$ [8]. However, the weight loss of polyurethane samples after the degradation in SBF was lower than in the case of degradation in mentioned phosphate buffer. It may be due to the fact that the molecules of salts were trapped between the macrochains of the polymer network and influenced on the samples weight.

Observed for PURs without a-PHB negligible decrease or even small increase of sample weight at the end of incubation could be explained by solid salt confined in polymer network.

The microscope images indicated that the presence of a-PHB in SSs appeared to protect polyurethanes against the salt sediments (Figs. 3, 4).

It was also observed that the sediment of solid salt on the surface of the polymer was larger after the incubation in $\mathrm{SBF}$ for polyurethanes synthesized at $\mathrm{NCO}: \mathrm{OH}=3.7: 1$

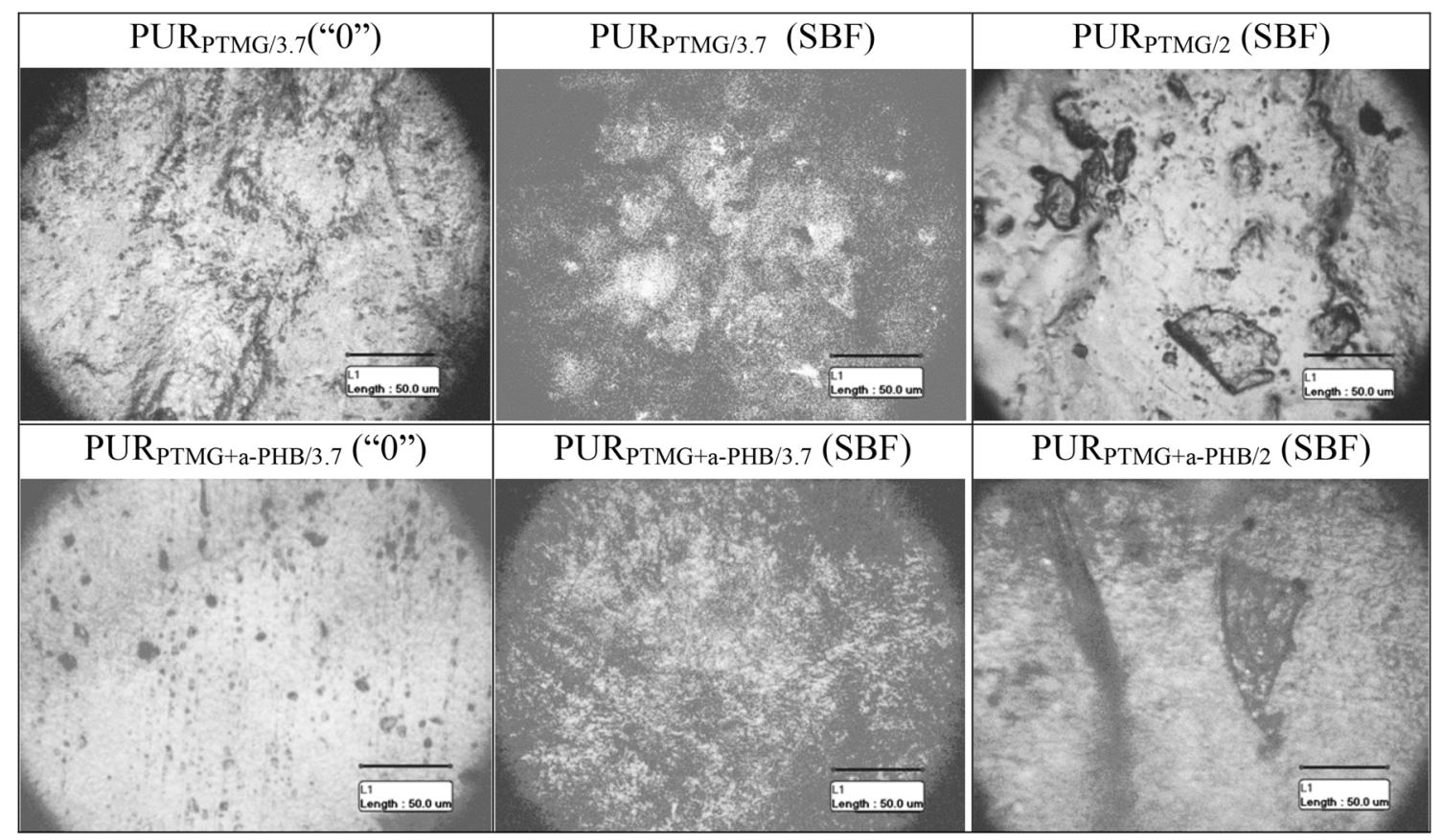

Fig. 3 Microscopic surface changes of polyetherurethane and polyether-esterurethane before ("0") and after 36 weeks of incubation in SBF 


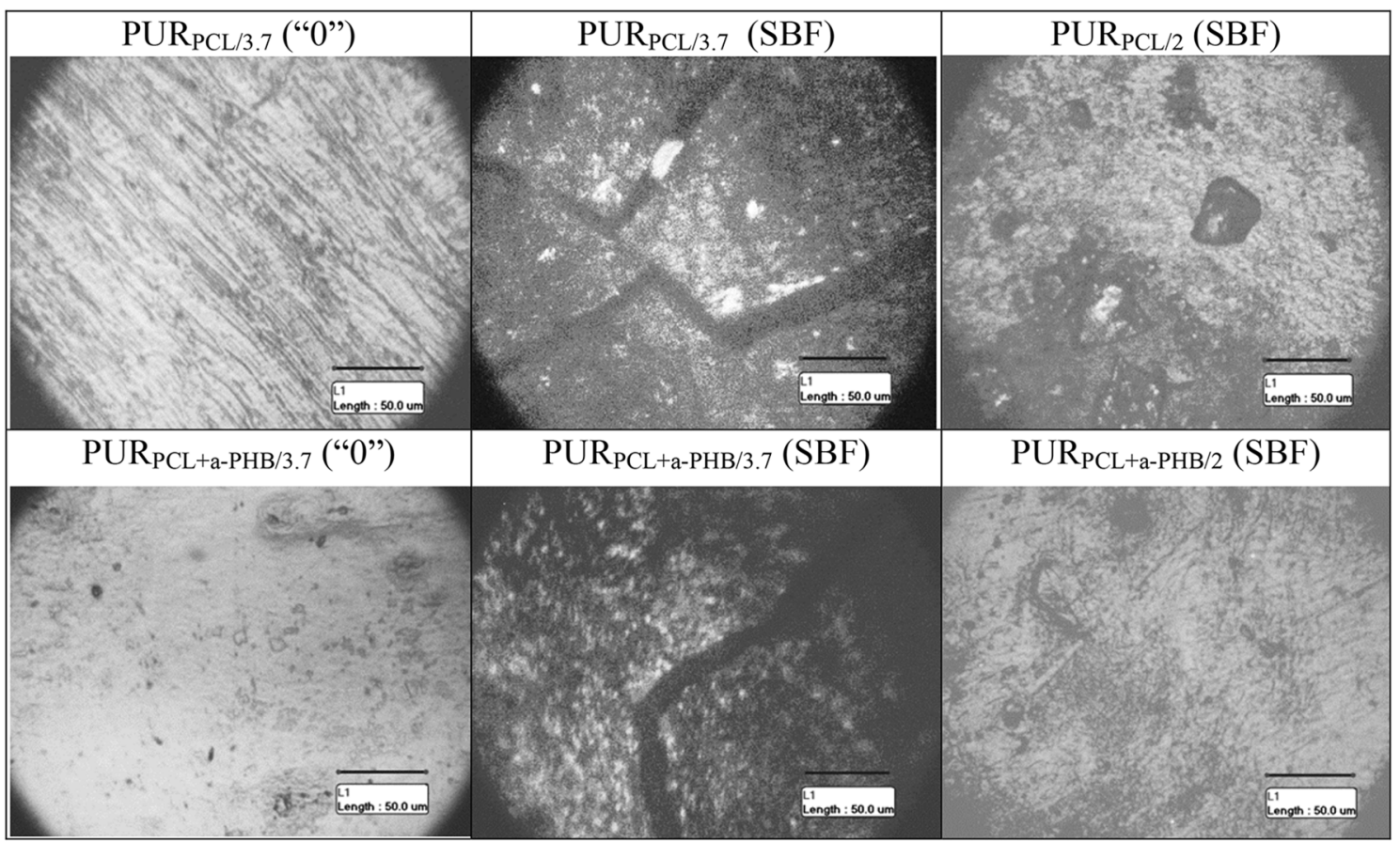

Fig. 4 Microscopic surface changes of polyesterurethane before and after 36 weeks of incubation in SBF

Table 2 Thermal properties of oligomerols

\begin{tabular}{lccc}
\hline Oligomerol & $\mathrm{T}_{\mathrm{g}}\left({ }^{\circ} \mathrm{C}\right)$ & $\mathrm{T}_{\mathrm{m} 1}\left({ }^{\circ} \mathrm{C}\right)$ & $\Delta \mathrm{H}_{1}(\mathrm{~J} / \mathrm{g})$ \\
\hline PTMG & -73.1 & 47.8 & 129.6 \\
PCL & -61.7 & 68.3 & 84.5 \\
a-PHB & -7.2 & 56.3 & 4.3
\end{tabular}

$\mathrm{T}_{\mathrm{g}}$ estimated from second heating run after rapid cooling

than at $\mathrm{NCO}: \mathrm{OH}=2: 1$ (in prepolymer step), what may indicate on their higher tendency to calcify. It could be caused by the generally higher hydrophobicity of PUR with molar ratio of $\mathrm{NCO}: \mathrm{OH}=2: 1$ in prepolymer [15]. The calcification process could be also connected with the structure of microchains. In case of higher amount of hard segments more binding sites for the formation of calcific nuclei were probably presented.

The polyurethanes synthesized at $\mathrm{NCO}: \mathrm{OH}=3.7: 1$ and susceptible to salt sediment were also more susceptible to degradation than synthesized at $\mathrm{NCO}: \mathrm{OH}=2: 1$ (in prepolymer step). Their surface was scored and cracked with black areas (Figs. 3, 4).

The same tendency as in case of incubation in SBF was observed for weight changes during the degradation in Ringer solution (Fig. 2).

The lower density of polyurethanes contained PTMG in SSs (in comparison to that obtained from PCL) caused, that degradative solutions could easy diffuse into the polymer structure [15].
The analytical data (glass temperature $\mathrm{T}_{\mathrm{g}}$ of SSs, $\mathrm{T}_{\mathrm{m}}$ and their enthalpy $\Delta \mathrm{H}$ ) from DSC curves of polyurethanes before and after degradation are summarized in Tables 3 and 5 for polyether-esterurethane and in Tables 4 and 6 for polyester-urethane. Thermal properties of oligomerols are presented in Table 2, for comparison.

The glass temperature $\mathrm{T}_{\mathrm{g}}$ of SSs of obtained polyurethanes (Tables 3, 4, 5, 6) was higher than the $\mathrm{T}_{\mathrm{g}}$ of a-PHB, PCL and PTMG monomers. This result indicated that the soft phase was influenced by the urethane hard segments, resulting in phase mixing. It may suggest the low phase separation, especially in case of polyurethanes based on PCL and a-PHB. Similar results were reported by Korley et al. [21], where $T_{g}$ of SSs of aliphatic polyurethanes only slightly increased from that of pure polyol, what was explained as a relatively small amount of hard segments mixing within the soft domain.

The investigated polyurethanes were only slightly crystalline (Tables 3, 4, 5, 6). For initial PUR $\mathrm{PCL}+\mathrm{a}-\mathrm{PHB} / 2_{2}$ a crystalline phase of a SS was observed on DSC curves as the endothermic peak with maximum at $70.1{ }^{\circ} \mathrm{C}$ and with $26.2 \mathrm{~J} / \mathrm{g}$ of melting enthalpy. In case of PUR $\mathrm{PCL}_{\mathrm{a}-\mathrm{PHB} / 3.7}$ where the content of SSs was lower, the arrangement of PCL was very difficult and crystals could not be created.

During incubation in both solutions some macrochains were cut, then reorganized and some small degree of crystallinity disappeared (e.g. PUR PTMG+a-PHB/3.7 and PUR $_{\mathrm{PCL}+\mathrm{a}-\mathrm{PHB} / 3.7}$ ) whereas another-appeared (e.g. $\mathrm{PUR}_{\mathrm{PTMG}+\mathrm{a}-\mathrm{PHB} / 2}$ and $\left.\mathrm{PUR}_{\mathrm{PCL}+\mathrm{a}-\mathrm{PHB} / 2}\right)$. As it was reported 
Table 3 Thermal properties of polyether-ester-urethane before and after incubation in SBF

\begin{tabular}{|c|c|c|c|c|c|}
\hline PUR (time of incubation) & $\mathrm{T}_{\mathrm{g}}\left({ }^{\circ} \mathrm{C}\right)$ & $\mathrm{T}_{\mathrm{m} 1}\left({ }^{\circ} \mathrm{C}\right)$ & $\Delta \mathrm{H}_{1}(\mathrm{~J} / \mathrm{g})$ & $\mathrm{T}_{\mathrm{m} 2}\left({ }^{\circ} \mathrm{C}\right)$ & $\Delta \mathrm{H}_{2}(\mathrm{~J} / \mathrm{g})$ \\
\hline PUR $_{\text {PTMG+a-PHB/3.7 }}$ (0 weeks) & -60.0 & 37.8 & 0.7 & $107.4 ; 135.9 ; 157.5$ & $2.5 ; 4.0 ; 2.2$ \\
\hline PUR $_{\text {PTMG+a-PHB/3.7 }}$ (4 weeks) & -23.5 & - & - & $93.9,130.0$ & $13.7,10.6$ \\
\hline $\mathrm{PUR}_{\mathrm{PTMG}+\mathrm{a}-\mathrm{PHB} / 3.7}$ (12 weeks) & -39.6 & - & - & 124.3 & 4.6 \\
\hline $\mathrm{PUR}_{\mathrm{PTMG}+\mathrm{a}-\mathrm{PHB} / 3.7}$ (24 weeks) & -16 & 51.1 & 7.2 & 111.8 & 4.5 \\
\hline $\mathrm{PUR}_{\mathrm{PTMG}+\mathrm{a}-\mathrm{PHB} / 3.7}$ (36 weeks) & 21.5 & 64.5 & 10.8 & 151.1 & 22.0 \\
\hline $\mathrm{PUR}_{\mathrm{PTMG}+\mathrm{a}-\mathrm{PHB} / 2}(0$ weeks $)$ & $-69.2 ; 10.6$ & - & - & 126.6 & 27.1 \\
\hline $\mathrm{PUR}_{\mathrm{PTMG}+\mathrm{a}-\mathrm{PHB} / 2}$ (4 weeks) & $-73.3 ; 2$ & 40.8 & 2.3 & 105.4 & 12.0 \\
\hline $\mathrm{PUR}_{\mathrm{PTMG}+\mathrm{a}-\mathrm{PHB} / 2}(24$ weeks) & $-71.3 ; 7.5$ & 37.3 & 1.5 & 121.7 & 15.3 \\
\hline PUR $_{\text {PTMG+a-PHB/2 }}$ (36 weeks) & $-73.2 ; 2.6$ & 48.8 & 1.8 & $110.6-143.2$ & 16.6 \\
\hline
\end{tabular}

$\mathrm{T}_{\mathrm{g}}$ estimated from second heating run after rapid cooling

Table 4 Thermal properties of polyester-urethane before and after incubation in SBF

\begin{tabular}{|c|c|c|c|c|c|}
\hline $\begin{array}{l}\text { PUR (time of } \\
\text { incubation) }\end{array}$ & $\begin{array}{l}\mathrm{T}_{\mathrm{g}} \\
\left({ }^{\circ} \mathrm{C}\right)\end{array}$ & $\begin{array}{l}\mathrm{T}_{\mathrm{m} 1} \\
\left({ }^{\circ} \mathrm{C}\right)\end{array}$ & $\begin{array}{l}\Delta \mathrm{H}_{1} \\
(\mathrm{~J} / \mathrm{g})\end{array}$ & $\begin{array}{l}\mathrm{T}_{\mathrm{m} 2} \\
\left({ }^{\circ} \mathrm{C}\right)\end{array}$ & $\begin{array}{l}\Delta \mathrm{H}_{2} \\
(\mathrm{~J} / \mathrm{g})\end{array}$ \\
\hline $\begin{array}{l}\mathrm{PUR}_{\mathrm{PCL}+\mathrm{a}-\mathrm{PHB} / 3.7} \\
(0 \text { weeks })\end{array}$ & -32.8 & 50.7 & 3.6 & $90.2 ; 138.1$ & $4.7 ; 9.1$ \\
\hline $\begin{array}{l}\text { PUR }_{\text {PCL }+\mathrm{a}-\mathrm{PHB} / 3.7} \\
\text { (4 weeks) }\end{array}$ & -26.5 & - & - & $82.4 ; 121.1$ & $14.1 ; 8.4$ \\
\hline $\begin{array}{l}\text { PUR }_{\text {PCL+a-PHB/3.7 }} \\
\text { (12 weeks) }\end{array}$ & -9.6 & - & - & $91.0 ; 124.1$ & $7.8 ; 5.3$ \\
\hline $\begin{array}{l}\text { PUR }_{\text {PCL }+\mathrm{a}-\mathrm{PHB} / 3.7} \\
\text { (24 weeks) }\end{array}$ & -9.7 & - & - & $99.6 ; 134.6$ & $23.0 ; 13.7$ \\
\hline $\begin{array}{l}\text { PUR }_{\text {PCL+a-PHB } / 3.7} \\
\text { (36 weeks) }\end{array}$ & 15.8 & 61.9 & 4.2 & $109.1 ; 133.2$ & 21.4 \\
\hline $\begin{array}{l}\text { PUR }_{\text {PCL }+\mathrm{a}-\mathrm{PHB} / 2} \\
(0 \text { weeks })\end{array}$ & -29.0 & 70.1 & 26.1 & 114.9 & 12.8 \\
\hline $\begin{array}{l}\text { PUR }_{\text {PCL }+\mathrm{a}-\mathrm{PHB} / 2} \\
\text { (4 weeks) }\end{array}$ & -34.5 & 50.8 & 22.7 & 106.4 & 8.8 \\
\hline $\begin{array}{l}\text { PUR }_{\text {PCL+a-PHB/2 }} \\
\text { (12 weeks) }\end{array}$ & -33.0 & 48.7 & 29.9 & 98.3 & 8.4 \\
\hline $\begin{array}{l}\text { PUR }_{\text {PCL+a-PHB/2 }} \\
\text { (24 weeks) }\end{array}$ & -34.0 & 49.8 & 31.2 & $104.0 ; 145.2$ & $10.0 ; 0.4$ \\
\hline $\begin{array}{l}\text { PUR }_{\text {PCL+a-PHB } / 2} \\
\text { (36 weeks) }\end{array}$ & -36.0 & 49.7 & 30.4 & 104.2 & 8.6 \\
\hline
\end{tabular}

$\mathrm{T}_{\mathrm{g}}$ estimated from second heating run after rapid cooling

by Hong et al. [22], during the incubation of polyurethane based on poly(3-caprolactone-co- $\beta$-butyrolactone) in hydrolytic solution, molecules of water diffused into the amorphous region and the degradation of polymer chains was easier. In consequence the mobility of chains increased which facilitates their crystallization.

The high exothermic peak on DSC thermograms with maximum in range of $164-177{ }^{\circ} \mathrm{C}$ and enthalpy even up to $95 \mathrm{~J} / \mathrm{g}$ for $\mathrm{PUR}_{\mathrm{PTMG}+\mathrm{a}-\mathrm{PHB} / 3.7}$ and $\mathrm{PUR}_{\mathrm{PCL}+\mathrm{a}-\mathrm{PHB} / 3.7}$ (degraded in both solutions) were observed. It indicated on high rate of degradation process of these polyurethanes, what was in agreement with observed weight loss (Fig. 1).
Table 5 Thermal properties of polyether-ester-urethane before and after incubation in Ringer solution

\begin{tabular}{|c|c|c|c|c|c|}
\hline $\begin{array}{l}\text { PUR (time of } \\
\text { incubation) }\end{array}$ & $\begin{array}{l}\mathrm{T}_{\mathrm{g}} \\
\left({ }^{\circ} \mathrm{C}\right)\end{array}$ & $\begin{array}{l}\mathrm{T}_{\mathrm{m} 1} \\
\left({ }^{\circ} \mathrm{C}\right)\end{array}$ & $\begin{array}{l}\Delta \mathrm{H}_{1} \\
(\mathrm{~J} / \mathrm{g})\end{array}$ & $\begin{array}{l}\mathrm{T}_{\mathrm{m} 2} \\
\left({ }^{\circ} \mathrm{C}\right)\end{array}$ & $\begin{array}{l}\Delta \mathrm{H}_{2} \\
(\mathrm{~J} / \mathrm{g})\end{array}$ \\
\hline $\begin{array}{l}\text { PUR }_{\text {PTMG }+\mathrm{a}-\mathrm{PHB} / 3.7} \\
(0 \text { weeks })\end{array}$ & -60.0 & 37.8 & 0.7 & $107.0-157.0$ & 9.0 \\
\hline $\begin{array}{l}\text { PUR }_{\text {PTMG+a-PHB/3.7 }} \\
\text { (4 weeks) }\end{array}$ & -60.0 & - & - & $80.0-134.3$ & 24.2 \\
\hline $\begin{array}{l}\text { PUR }_{\text {PTMG+a-PHB } / 3.7} \\
\text { (12 weeks) }\end{array}$ & -27.0 & - & - & $80.0-141.0$ & 24.6 \\
\hline $\begin{array}{l}\text { PUR }_{\text {PTMG }+\mathrm{a}-\mathrm{PHB} / 3.7} \\
\text { (24 weeks) }\end{array}$ & -29.8 & - & - & $80.0-134.1$ & 19.2 \\
\hline $\begin{array}{l}\text { PUR }_{\text {PTMG }+\mathrm{a}-\mathrm{PHB} / 3.7} \\
\text { (36 weeks) }\end{array}$ & -25.3 & - & - & $80.0-134.6$ & 15.7 \\
\hline
\end{tabular}

$\mathrm{T}_{\mathrm{g}}$ estimated from second heating run after rapid cooling

The similar exothermic processes were not observed for PURs with lower NCO:OH ratio.

Different changes in polyurethanes structure after incubation in both solutions studied were observed, depending on SSs structure and molar ratio of $\mathrm{NCO}: \mathrm{OH}$ in prepolymer step.

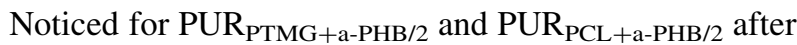
the incubation in SBF (Tables 3,4) and in Ringer solution (Table 6) decreasing of $T_{g}$ was probably the result of increasing of chains mobility after their scission [23].

However, for polyurethanes obtained at $\mathrm{NCO}: \mathrm{OH}=$ 3.7:1 in prepolymer and degraded both in SBF and in Ringer solutions (Tables 3, 4, 5, 6) $\mathrm{T}_{\mathrm{g}}$ shifted to the higher temperatures in comparison to that of non degraded PURs samples. This could be explained by considerable structural changes connected with the reduction of chain lengths followed by eventual physical crosslinking of macromolecules after degradation [18, 24].

Generally it could be stated, that more significant changes of thermal properties observed after degradation of polyurethanes synthesized with higher content of hard segments confirmed their higher degradability. 
Table 6 Thermal properties of polyester-urethane before and after incubation in Ringer solution

\begin{tabular}{|c|c|c|c|c|c|}
\hline PUR (time of incubation) & $\mathrm{T}_{\mathrm{g}}\left({ }^{\circ} \mathrm{C}\right)$ & $\mathrm{T}_{\mathrm{m} 1}\left({ }^{\circ} \mathrm{C}\right)$ & $\Delta \mathrm{H}_{1}(\mathrm{~J} / \mathrm{g})$ & $\mathrm{T}_{\mathrm{m} 2}\left({ }^{\circ} \mathrm{C}\right)$ & $\Delta \mathrm{H}_{2}(\mathrm{~J} / \mathrm{g})$ \\
\hline PUR $_{\text {PCL+a-PHB/3.7 }}(0$ weeks $)$ & -32.8 & 50.7 & 3.6 & $90.2 ; 138.1$ & $4.7 ; 9.1$ \\
\hline PUR $_{\text {PCL+a-PHB/3.7 }}$ (12 weeks) & -33.2 & - & - & 129.7 & 27.8 \\
\hline $\mathrm{PUR}_{\mathrm{PCL}+\mathrm{a}-\mathrm{PHB} / 3.7}$ (24 weeks) & -34.4 & - & - & 125.8 & 23.2 \\
\hline $\mathrm{PUR}_{\mathrm{PCL}+\mathrm{a}-\mathrm{PHB} / 3.7}$ (36 weeks) & -13.2 & - & - & 127.9 & 25.5 \\
\hline $\mathrm{PUR}_{\mathrm{PCL}+\mathrm{a}-\mathrm{PHB} / 2}(0$ weeks $)$ & -29.0 & 70.1 & 26.2 & 114.9 & 12.8 \\
\hline $\mathrm{PUR}_{\mathrm{PCL}+\mathrm{a}-\mathrm{PHB} / 2}$ (4 weeks) & -30.0 & 57.1 & 26.8 & 106.8 & 8.0 \\
\hline $\mathrm{PUR}_{\mathrm{PCL}+\mathrm{a}-\mathrm{PHB} / 2}(12$ weeks $)$ & -29.0 & 54.7 & 26.1 & 106.2 & 7.8 \\
\hline $\mathrm{PUR}_{\mathrm{PCL}+\mathrm{a}-\mathrm{PHB} / 2}$ (24 weeks) & -32.5 & 55.3 & 27.8 & 103.1 & 11.4 \\
\hline $\mathrm{PUR}_{\mathrm{PCL}+\mathrm{a}-\mathrm{PHB} / 2}$ (36 weeks) & -30.1 & 53.8 & 28.3 & 104.0 & 12.3 \\
\hline
\end{tabular}

$\mathrm{T}_{\mathrm{g}}$ estimated from second heating run after rapid cooling

\section{Conclusion}

The results of this study revealed that the polyurethanes synthesized at molar ratio of $\mathrm{NCO}: \mathrm{OH}=3.7: 1$ appeared more susceptible to degradation in SBF and Ringer balanced salt solution as well as to salt sedimentation when compared with polyurethanes obtained at $\mathrm{NCO}: \mathrm{OH}=2: 1$ (in prepolymer step). Thermal properties observed after degradation of polyurethanes with higher content of hard segments also confirmed their higher degradability.

The presence of a-PHB in the structure of investigated polyurethanes accelerated their degradation in both solutions studied, protected them against the calcification process and affected their morphology. Polyurethane with PTMG and a-PHB in SSs and synthesized at $\mathrm{NCO}: \mathrm{OH}=3.7: 1$ in prepolimer step was the most susceptible to degradation in simulated body fluids.

It could be stated that polyurethanes based on atactic a-PHB displayed the properties appropriate for further investigations for medical application as e.g. degradable scaffolds.

Open Access This article is distributed under the terms of the Creative Commons Attribution License which permits any use, distribution, and reproduction in any medium, provided the original author(s) and the source are credited.

\section{References}

1. Efe T, Getgood A, Schofer MD, Fuchs-Winkelmann S, Mann D, Paletta JRJ, Heyse TJ (2012) Knee Surg Sports Traumatol Arthrosc 20:1822

2. Mândru M, Ciobanu C, Vlad S, Butnaru M, Lebrun L, Popa M (2013) Cent Eur J Chem 11(4):542
3. Mondal S, Martin D (2012) Polym Degrad Stab 97:1553

4. Santerre JP, Woodhouse K, Laroche G, Labow RS (2005) Biomaterials $26: 7457$

5. Zawidlak-Węgrzyńska B, Kawalec M, Bosek I, Łuczyk-Juzwa M et al (2010) Eur J Med Chem 45:1833

6. Piddubnyak V, Kurcok P, Matuszowicz A, Głowala M, FiszerKierzkowska A, Jedliński Z, Juzwa M, Krawczyk Z (2004) Biomaterials 25:5271

7. Brzeska J, Dacko P, Janeczek H, Kowalczuk M, Janik H, Rutkowska M (2011) Polimery 56(1):27

8. Brzeska J, Dacko P, Heimowska A, Janik H, Kowalczuk M, Rutkowska M (2012) Ochrona przed korozją 1:8

9. Brzeska J, Dacko P, Gębarowska K, Janik H, Kaczmarczyk B, Kasperczyk J, Kowalczuk M, Rutkowska M (2012) J Appl Polym Sci 125(6):4285

10. Brzeska J, Kowalczuk M, Janik H, Rutkowska M (2012) Zeszyty naukowe Akademii Morskiej w Gdyni. Jt Proc 74:5

11. Brzeska J, Janik H, Kowalczuk M, Rutkowska M (2011) Eng Biomater 65(XIV):106-108

12. Brzeska J, Janik H, Kowalczuk M, Rutkowska M (2011) Eng Biomater 73(XIV):106-108

13. Brzeska J, Dacko P, Janik H, Kowalczuk M, Rutkowska M (2012) Biodegradowalne poliuretany i sposób ich wytwarzania, PL Patent Number 212763

14. Arslan H, Adamus G, Hazer B, Kowalczuk M (1999) Rapid Commun Mass Spectrom 13:2433

15. Brzeska J (2010) Thesis Gdynia Maritime University

16. Kokubo T, Takadama H (2006) Biomaterials 27:2907

17. Wan Y, Wen D (2005) J Membr Sci 246:193

18. Wojturska J (2011) Polimery 56(3):177

19. Umare SS, Chandure AS (2008) Chem Eng J 142:65

20. Hepburn C (1992) Polyurethane elastomers. Elsevier, London

21. Korley LTJ, Pate BD, Thomas EL, Hammond PT (2006) Polymer 47:3073

22. Hong JH, Jeon HJ, Yoo JH, Yu W-R, Youk JH (2007) Polym Degrad Stab 92:1186

23. Feng Y, Li C (2006) Polym Degrad Stab 91(8):1711

24. Ryszkowska J, Auguścik M, Sheikh A, Boccaccini AR (2010) Compos Sci Technol 70:1894 